\title{
A REVIEW OF ESTONIAN ORDOVICIAN RAFINESQUINIDS (BRACHIOPODA, STROPHOMENACEA)
}

\author{
Arvo ROOMUSOKS
}

Tartu Olikooli Geoloogia Instituut (Institute of Geology, Tartu University), Vanemuise 46, EE-2400 Tartu, Eesti (Estonia)

Received March 8, 1993; accepted May 28, 1993

Abstract. In the Estonian Ordovician four genera of rafinesquinids occur. The occurrence of Kjaerina Bancroft, 1929 in the Oandu Stage is the first record of this genus in the Ordovician of northern East Baltic. Two species - $K$. poljensis (Alichova, 1951 ) and K. orvikui (Männil) are redescribed. Three new genera - Rakverina, Harjumena, and Pirgumena - are erected. The last genus is represented in the Pirgu Stage with $P$. martnai sp. n.

Key words: Strophomenida, Ordovician, Estonia.

Salmon (1942) subdivided the old, familiar genus Rafinesquina into Oepikina and Rafinesquina s. str. Afterwards only seven rafinesquinids have been described from the Ordovician of Estonia and Ingria, St. Petersburg District, Russia. These are Rafinesquina poljensis Alichova, 1951, Oepikina ? inaequiclina Alichova, 1951, R. $(R)$ corrugatella (Davidson), $R$. (R.) expansa (Sowerby), and Leptaena schmidti (Gagel), described by Sokolskaya (Сокольская, 1954), R. (R.) orvikui Männil and R. (Playfairia) ? oanduensis Oraspõld described by Oraspõld (Opacпыльд, 1956). In none of these species interiors were known. The purpose of this paper is to briefly revise these species. In addition, three new genera, Rakverina, Harjumena, and Pirgumena are erected. The occurrence of Kjaerina in the Oandu Stage is the first record of this genus in the Ordovician of northern East Baltic. Kjaerina appeared in the Baltic region at the end of the Viru Epoch, approximately at the same time as it entered Britain (Hurst, 1979). This was the time of a notable exchange between faunas of several regions (Jaanusson, 1979; Jaanusson $\&$ Bergström, 1980). The new genera of the rafinesquinids described in this paper appeared at the end of the Viru Epoch and during the Harju Epoch.

The types and figured specimens are housed in the Museum of Geology at Tartu University (GMUT Br marking the catalogue numbers of the brachiopod types). 
Family Rafinesquinidae Schuchert, 1893

Genus Kjaerina Bancroft, 1929

Kjaerina poljensis (Alichova, 1951)

Pl. I, figs. $1-4$

1951 Rafinesquina poljensis Alichova; Алихова, p. 48; P1. IV, figs. $76,77$.

non 1954 Rafinesquina (Rafinesquina) poljensis (Alichova), Sokolskaya (Сокольская, р. 37); P1. I, figs. 1, 2 (=Kjaerina sp n.).

Diagnosis (emended): Large Kjaerina (known maximum width of the shell $35 \mathrm{~mm}$ ) with almost flat, very thin shell, subrectangular in outline. One or two strong medial costae. Irregular posterolateral wrinkles faint or absent. Pseudodeltidium vestigial, chilidium large, medially grooved. Ventral muscle field large, with long, straight, broadly divergent bounding ridges. Dental plates short. Posterior platform weakly developed, cardinal process lobes anteriorly broadly divergent. Coarse, sparsely placed and radially arranged tubercles.

Distribution. Oandu Stage, Hirmuse Formation (U. Caradoc), North Estonia and Ingria, Russia.

Alichova (Алихова, 1951 р. 49) erroneously reported this species from the Jõhvi and Keila beds, a mistake corrected by Männil (Мянниль, 1960 p. 95). The specimens referred by Sokolskaya (Сокольская, 1954 р. 37) as $R$. (R.) poljensis belong to a new species, which occurs only in the north-western part of Estonia (Oandu Stage, Saku Member of the Vasalemma Formation).

Kjaerina orvikui (Männil), Ораспыльд, 1956 Pl. I, figs. $5-7$

1956 Rafinesquina (Rafinesquina) orvikui Männil, Ораспыльд, p. 49; Pl. I, fig. 21 .

Diagnosis (emended): Small Kjaerina (known maximum width of the valve $14 \mathrm{~mm}$ ) with moderately convex ventral valve, semicircular in outline. Dorsal valve correspondingly concave. Ornamentation weakly unequally parvicostellate. Medial accentuated costa fine. Few weak posterolateral wrinkles. Ventral muscle field small, weakly depressed. Dental plates very short. Pseudodeltidium vestigial, chilidium large, medially grooved. Cardinal process lobes long, subparallel. Posterior platform delicate. Fine tubercles, arranged radially.

Distribution. Oandu Stage, Hirmuse Formation (U. Caradoc), North Estonia and Ingria, Russia.

\section{Genus Rakverina nov.}

Name: After occurrence of the type species in the Rakvere Stage.

Type species. Oepikina (?) inaequiclina Alichova (Алихова, 1951; p. 58, Pl. IV, figs. 69-71) from the Rakvere Stage (U. Caradoc), North Estonia and Ingria, Russia.

Diagnosis: Medium-sized Rafinesquinidae (known maximum width of the interarea $35 \mathrm{~mm}$ ) with convex shell, subtriangular in outline and strongly geniculated in dorsal direction. Ventral disc weakly convex or almost flat with slightly swollen umbonal part. Dorsal disc weakly concave. Trail longer than disc, mostly somewhat rounded. Ornament unequally parvicostellate with densely spaced sharp accentuated costellae, Coarse concentric wrinkles variously developed on both valves, 
particularly posterolaterally. Ventral interarea long. Pseudodeltidium absent, chilidium with triangular medial groove. Ventral muscle field subcircular, weakly depressed, with low posteriorly curved lateral bounding ridges. Dental plates short. Posterior platform indistinct with short narrow posteriorly striated socket plates. Blade-like, subparallel cardinal process lobes. No true transmuscle septa. Sparse coarse tubercles.

Species assigned:

Oepikina (?) inaequiclina Alichova, 1951 (Алихова, р. 58) (Р1. II, figs. $6-11$ in the present paper) from the Rakvere Stage.

Rafinesquina (Playfairia) ? oanduensis Oraspõld (Ораспыльд, 1956 p. 50; Pl. I, fig. 20) (Pl. II, figs. $1-5$ in the present paper) from the Oandu Stage, Hirmuse Formation, North Estonia.

Comparison. Rakverina differs from Kjaerina in having a more convex ventral valve with relatively flatter disc, commonly coarse concentric wrinkles, subcircular ventral muscle field, weaker posterior platform, and no prominent medial costa.

Distribution. Oandu Stage, Hirmuse Formation and Rakvere Stage (U. Caradoc), North Estonia and Ingria, Russia.

\section{Genus Harjumena nov.}

Name: After occurrence of the type species of the genus in the province of Harjumaa in Estonia.

Type species. Strophomena schmidti Gagel, 1890 p. 42 ; Pl. III, fig. 4 from erratic boulders in former East Prussia (now Kaliningrad District). Most probably derived from the Nabala Stage.

Diagnosis: Large Rafinesquinidae (known maximum width of the interarea up to $64 \mathrm{~mm}$ ) with subtriangular shell abruptly geniculated in dorsal direction. Disc in both valves almost flat. Ornamentation strongly unequally parvicostellate with coarse, weakly irregular accentuated costellae and irregularly arranged concentric corrugations on the whole disc. Pseudodeltidium vestigial, chilidium large, medially grooved. Ventral muscle field elongate, weakly depressed. Dental plates short.

\section{Species assigned:}

Strophomena schmidti Gagel, 1890 (P1. III, figs. 1-7 in the present paper) from the Nabala Stage, Saunja Formation (L. Ashgill), North Estonia.

Rafinesquina (?) schmidti Gagel in Holtedahl 1916 p. 32; Pl. III, fig. 1 (=Harjumena sp. n.) from the basal part of the $4 \mathrm{~d}$ beds (Ashgill), Hadeland in the Oslo Region, Norway.

Rafinesquina (?) sp. (R. schmidti Gagel ?) in Holtedahl 1916 p. 32; Pl. III, fig. 2 (=Harjumena sp.n.) from the $4 \mathrm{~d}$ beds (Ashgill), Ringerike in the Oslo Region, Norway.

Harjumena sp. n. (P1. III, figs. 8 and 9 in the present paper) from the Vormsi Stage, Körgessaare Formation (Ashgill), North Estonia.

Discussion. Harjumena resembles Rakverina, in particular $R$. oanduensis (Oraspõld), but differs in attaining a much larger size, having fine, irregular concentric corrugations all over the disc, a narrow, elongate ventral muscle field, and a narrow dorsal medial septum. Despite the large size of the valves the shell is very thin. The type species was described and figured by Sokolskaya (Сокольская, 1954 p. 59; Pl. III, fig. 14) as 
Leptaena schmidti and as Rafinesquina (Rafinesquina) corrugatella (Davidson) (Сокольская, 1954 р. 38; Pl. III, fig. 3), both from the Nabala Stage, Saunja Formation, from exposures at Tapa and Tõrma, North Estonia. I have examined the types of Sokolskaya in the Paleontological Museum in Moscow and I am convinced that the two specimens figured by her (Сокольская, 1954; Pl. III, figs. 15 and 16) as Leptaena schmidti represent actually Bekkeromena $\mathrm{sp}$. $\mathrm{n}$.

I have examined the specimens described by Holtedahl (1916) as Rafinesquina (?) schmidti and Rafinesquina (?) sp. ( $R$. schmidti Gagel ?) from $4 \mathrm{~d}$ beds in Norway and they obviously belong to two separate new species of Harjumena, attaining a still larger size than H. schmidti.

Distribution. Harju Series (Ashgill) in Baltoscandia. Nabala Stage, Saunja Formation and Vormsi Stage, Kõrgessaare Formation in North Estonia; 4d beds, Hadeland and Ringerike in the Oslo Region, Norway.

\section{Genus Pirgumena nov.}

Name: After occurrence of the type species in the Pirgu Stage.

Type species. Pirgumena martnai sp. n. from the Pirgu Stage, Adila Formation including the Röa Member (M. Ashgill), North Estonia.

Diagnosis: Large Rafinesquinidae (known maximum width at the hinge line $65 \mathrm{~mm}$ ), shell very thin, valves semicircular to subtriangular in outline. Ventral valve flat, except the umbonal part, which is slightly but distinctly convex. Dorsal valve almost flat but slightly concave in elongated umbonal part. Ornamentation unequally parvicostellate with numerous high and rounded accentuated costellae. Pseudodeltidium small, narrow. Chilidium large, not grooved. Ventral muscle field without lateral bounding ridges. Dental plates short. Posterior platform delicatè, Kjaerina-like with long narrow medial ridge. Socket plates thin, short. Cardinal process lobes strong, broadly diverging anteriorly. Shell substance with radially arranged coarse and sparse tubercles.

\section{Species assigned:}

Pirgumena martnai sp. n. from the Pirgu Stage of Estonia.

Rafinesquina (Rafinesquina) expansa (Sowerby) in Sokolskaya (Coкольская, 1954 p. 39; Pl. I, figs. 4-13 (=Pirgumena sp. n.; Pl. IV, fig. 7 in the present paper). This species was mentioned by Schmidt (1908 p. 725) as a large flat form from the Porkuni Stage with alternating coarser and finer costellae, probably identical with Strophomena luna Törnquist from the Leptaena Limestone (=Boda Limestone in Sweden).

Discussion. Pirgumena and Aphanomena Bergström, 1968, are among the largest and flattest rafinesquinids known. Both genera have large shells but while the valves of Aphanomena are almost completely flat, in Pirgumena the umbonal portion of the ventral valve is distinctly convex and that of the dorsal valve slightly but conspicuously concave. Pirgumena differs from Aphanomena in having a somewhat thicker shell, more prominent posterior platform, shorter dental plates, and distinctly coarser tubercles (P1. IV, fig. 6). The available interiors of the Pirgumena moulds are from the dolomitic limestone of the Röa Member. For that reason the morphology of the cardinal process and socket plates is not known in detail. Relative to the size of the shell the cardinalia of Aphanomena is remarkably small. In Pirgumena the relative size of the cardinalia is larger. 
Distribution. Pirgu and Porkuni stages (Ashgill), North Estonia.

Pirgumena martnai sp. n.

Pl. IV, figs. $1-6$

Name: After the Estonian geologist Dr. Jüri Martna.

1957 Rafinesquina? sp., Martna p. 29 (named only).

1991 Aphanomena sp. n. 1, Rõõmusoks; Pыымусокс, P1. IV, figs. 1-4.

Holotype. Ventral valve (GMUT Br 1471) (P1. IV, figs. 5 and 6) from the Pirgu Stage, Adila Formation (M. Ashgill), at the Atla River, Pirgu. North Estonia, coll. author, 1959.

Diagnosis: Shell large (estimated maximum width at the hinge line $65 \mathrm{~mm})$, very thin, semicircular in outline. Ventral valve generally flat but weakly swollen in umbonal region up to posterior third part of the valve. Umbonal portion of the dorsal valve correspondingly concave. Ventral interarea apsacline. No foramen. Pseudodeltidium high but narrow. Chilidium unknown. Commonly 8-10 costellae per $2 \mathrm{~mm}$ at the anterior margin. Costellae with very fine, dense spaced concentric fila. No conspicuous posterolateral wrinkles. Ventral interior short, broadly diverging dental plates. Cardinal process lobes strong, socket plates short. Tubercles relatively coarse, radially arranged.

Distribution. Pirgu Stage, Adila Formation including the Röa Member, North Estonia.

\section{ACKNOWLEDGEMENTS}

The author expresses his thanks to Prof. V. Jaanusson (Swedish Museum of Natural History) for valuable discussions, criticism, and some photographs of the Scandinavian species.

\section{PLATE I}

Figs. 1-4. Kjaerina poljensis (Alichova), all from Oandu Stage, Hirmuse Formation. 1 - dorsal interior (X4.3) (GMUT $\mathrm{Br}$ 1618). Rakvere, coll. A. Öpik. 2 - ventral view $(X 1)$ (GMUT $\mathrm{Br} 1635)$. Törremägi, coll. author, 1955. 3 - ventral view $(\times 2)$ (GMUT Br 1620). Oandu, coll. A. Opik. 4 - ventral interior ( $\times 2)$ (GMUT Br 1621). Rakvere, coll. A. Opik. Figs. 5-7. Kjaerina orvikui (Männil), all from Oandu Stage, Hirmuse Formation. 5 - ventral view of holotype (X2) (TAGI $\mathrm{Br} 3058$ ). Oandu. 6 dorsal interior $(\times 5.5)$ (GMUT $\mathrm{Br} 1623)$. Törremägi, coll. H. Palmre, 1937. 7 ventral interior (X5) (GMUT Br 1622). Tõrremägi, coll. H. Palmre, 1937.

\section{PLATE II}

Figs. 1-5. Rakverina oanduensis (Oraspõld), all from Oandu Stage, Hirmuse Formation. $1-3$ - ventral, lateral, and posterior views of the holotype $\left(X_{2}\right)$ (TAGI $\mathrm{Br} 3082$ ). Oandu. 4 - dorsal interior (X2). (GMUT $\mathrm{Br} 1631)$. Törremägi, coll. H. Palmre, 1937. 5 - ventral interior $(\times 2)$ (GMUT $\mathrm{Br} 1632$ ). Törremägi, coll. H. Palmre, 1937. Figs. 6-11. Rakverina inaequiclina (Alichova), all from Rakvere Stage, Piilse Member of the Rägavere Formation. 6-8 - dorsal, ventral, and lateral views (X2) (GMUT $\mathrm{Br}$ 1560). Rägavere, coll. K. Orviku. 9 - dorsal interior (X2) (GMUT Br 1630). Rägavere, coll. Fr. Schmidt. 10 - posterior view (X3.6) (GMUT $\mathrm{Br} 1479)$. Rakvere, coll. G. Mechmershausen. 11 - ventral interior $(\times 3)$ (GMUT Br 1482). Rägavere, coll. V. Paul. 
PLATE I
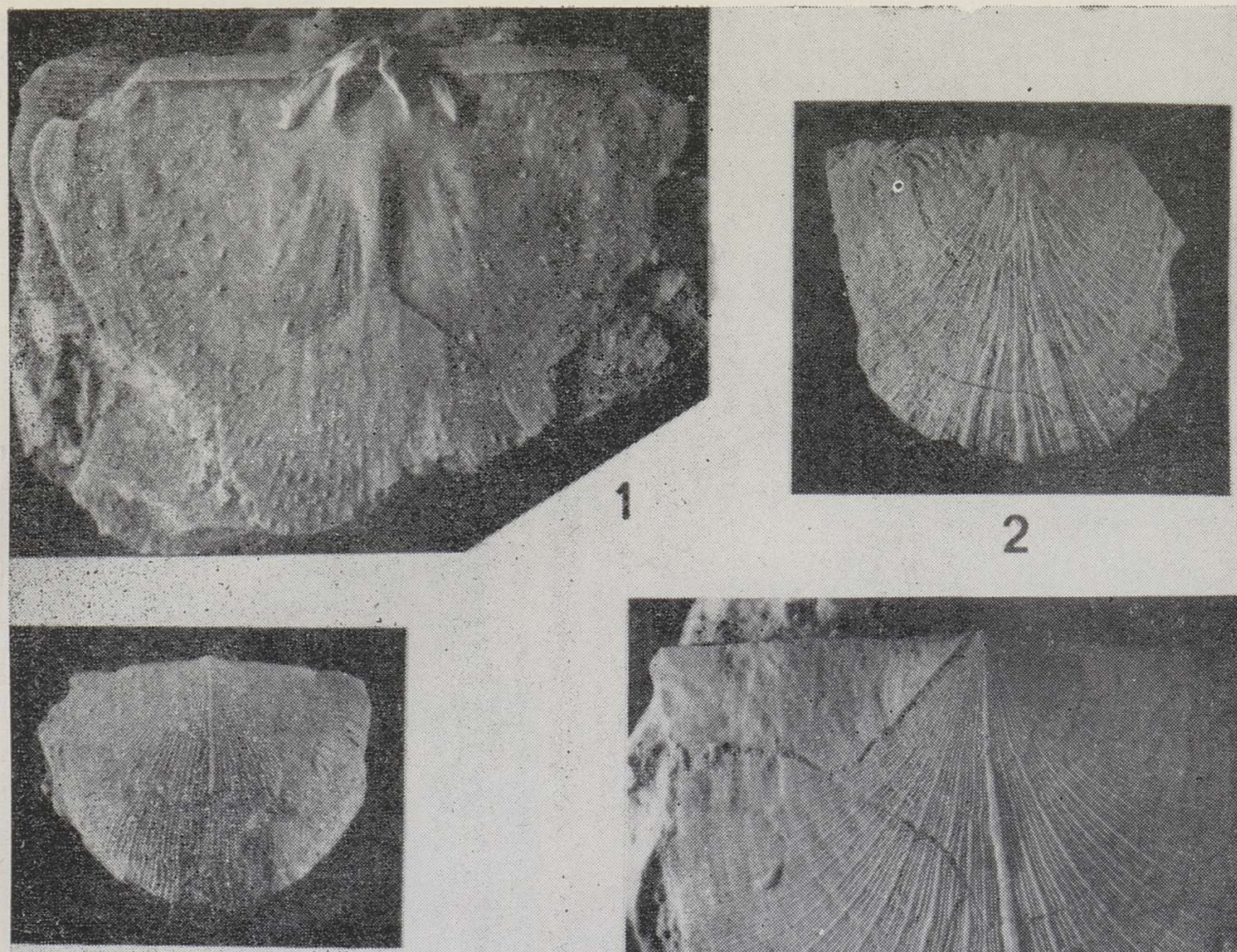

5
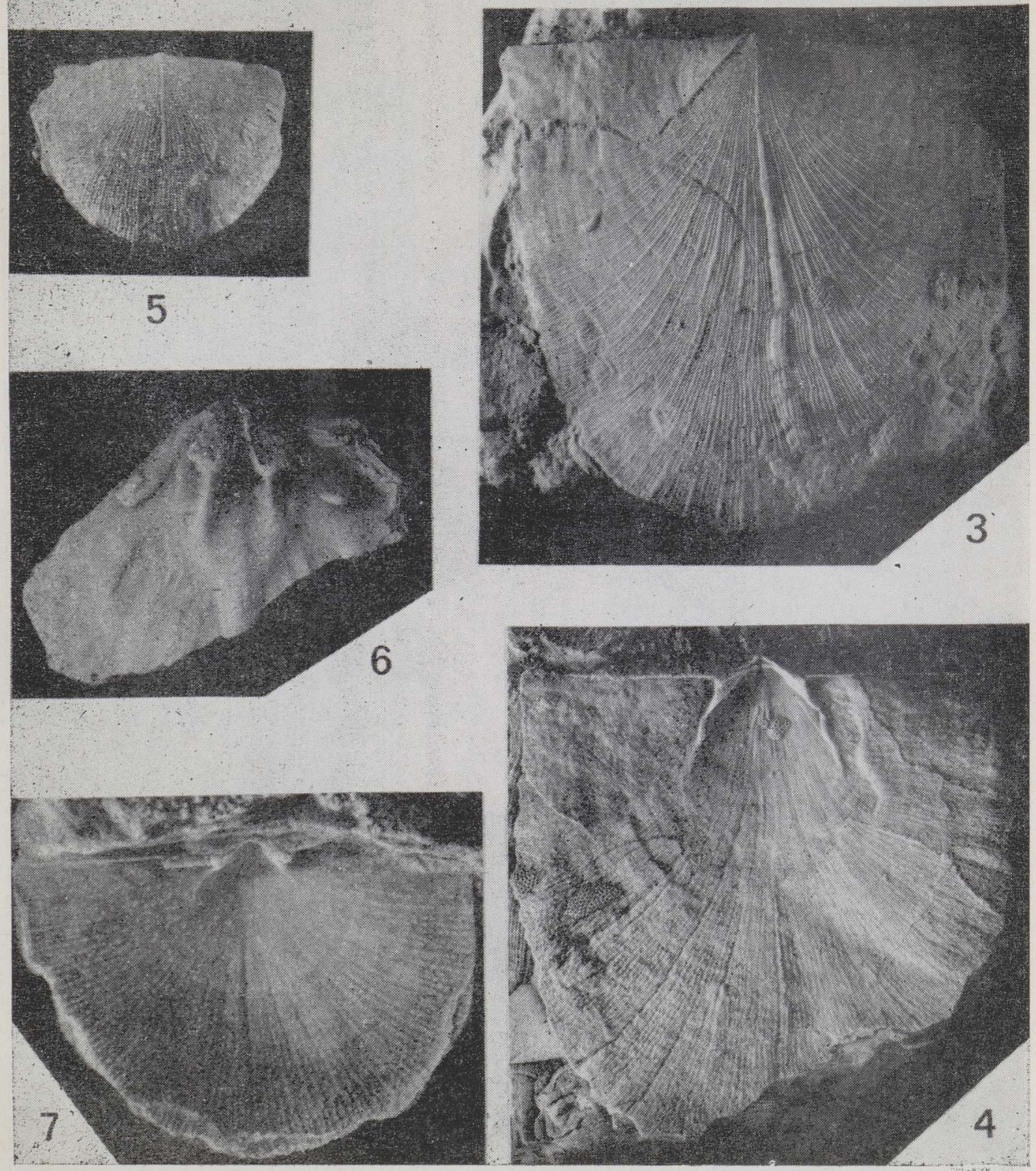
PLATE II

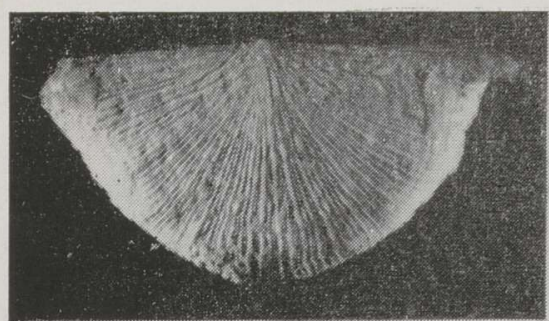

1
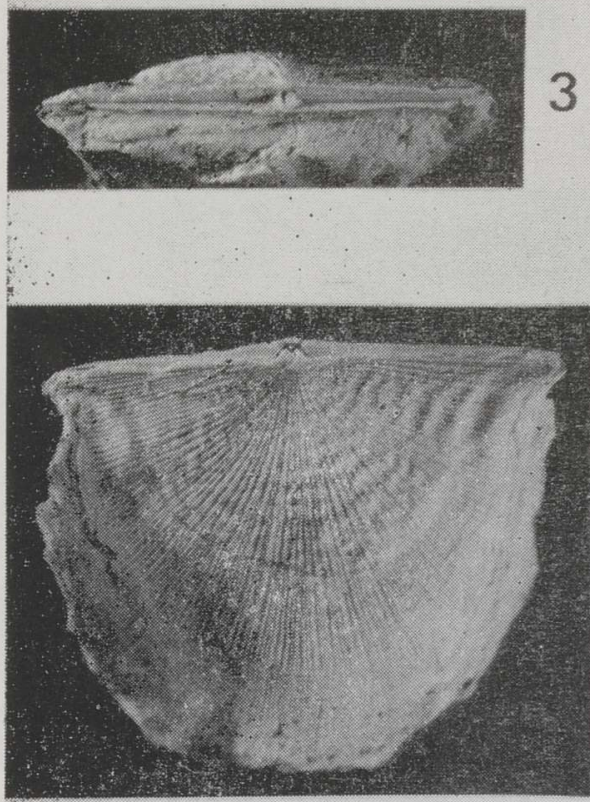

6

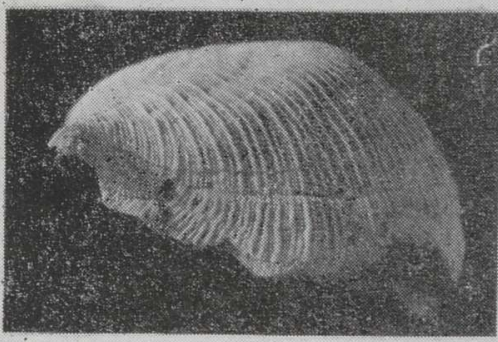

8

10

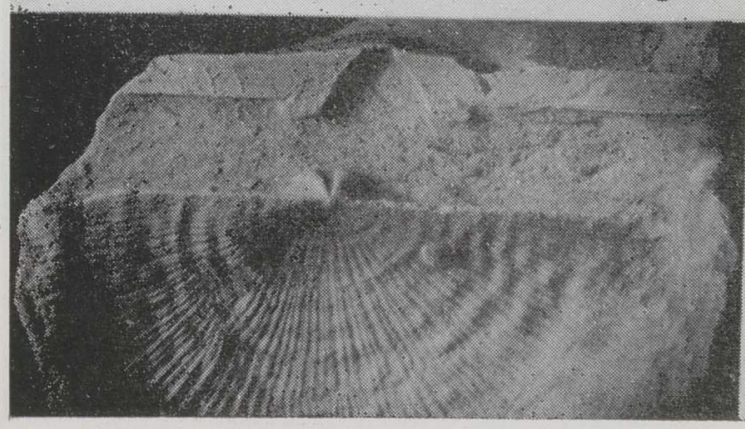

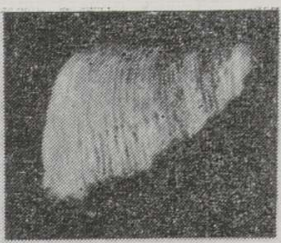

2
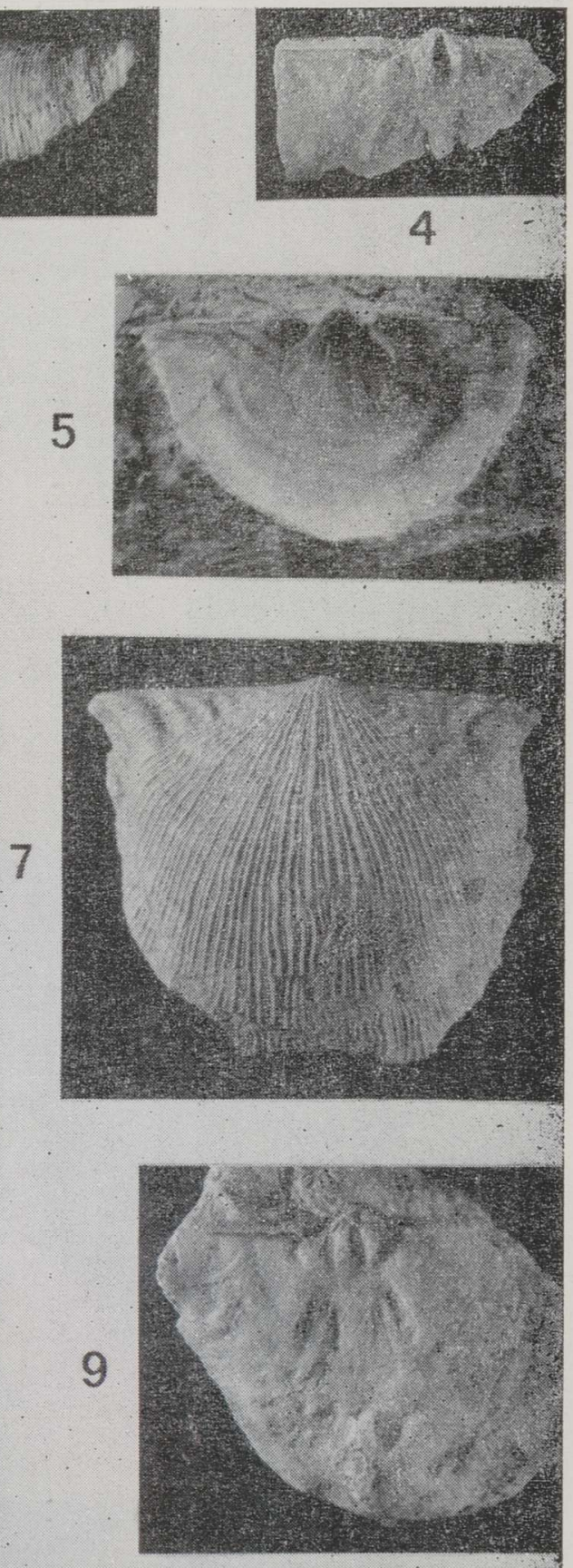

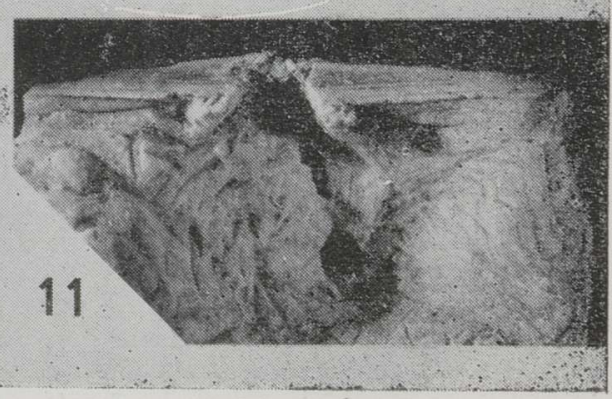


PLATE III
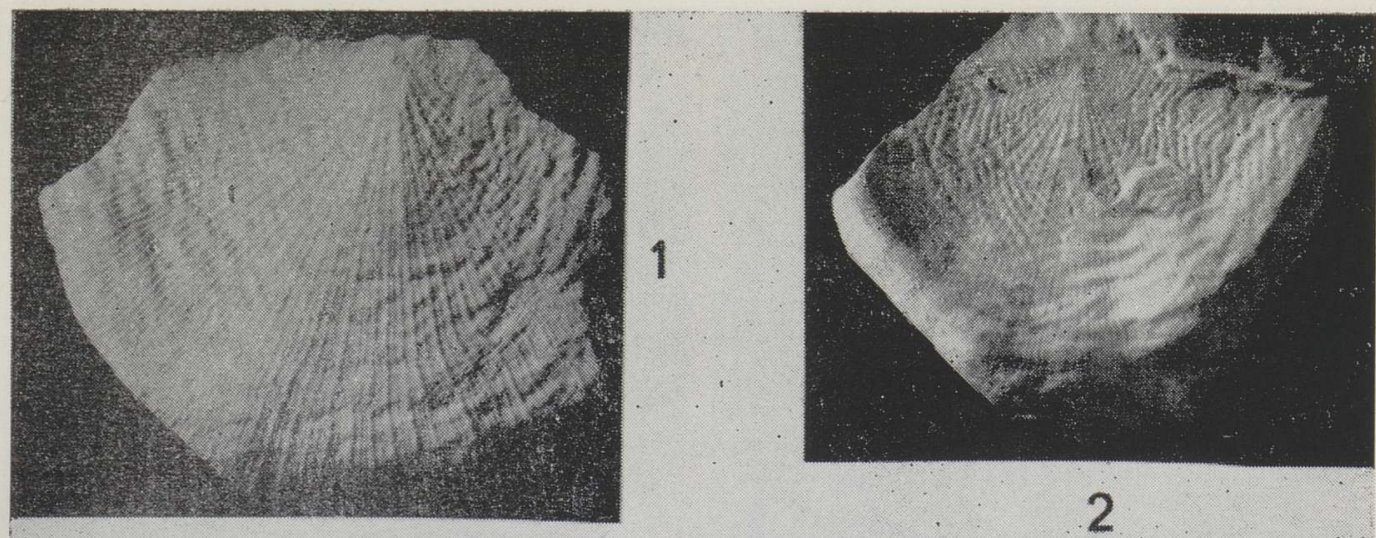

2
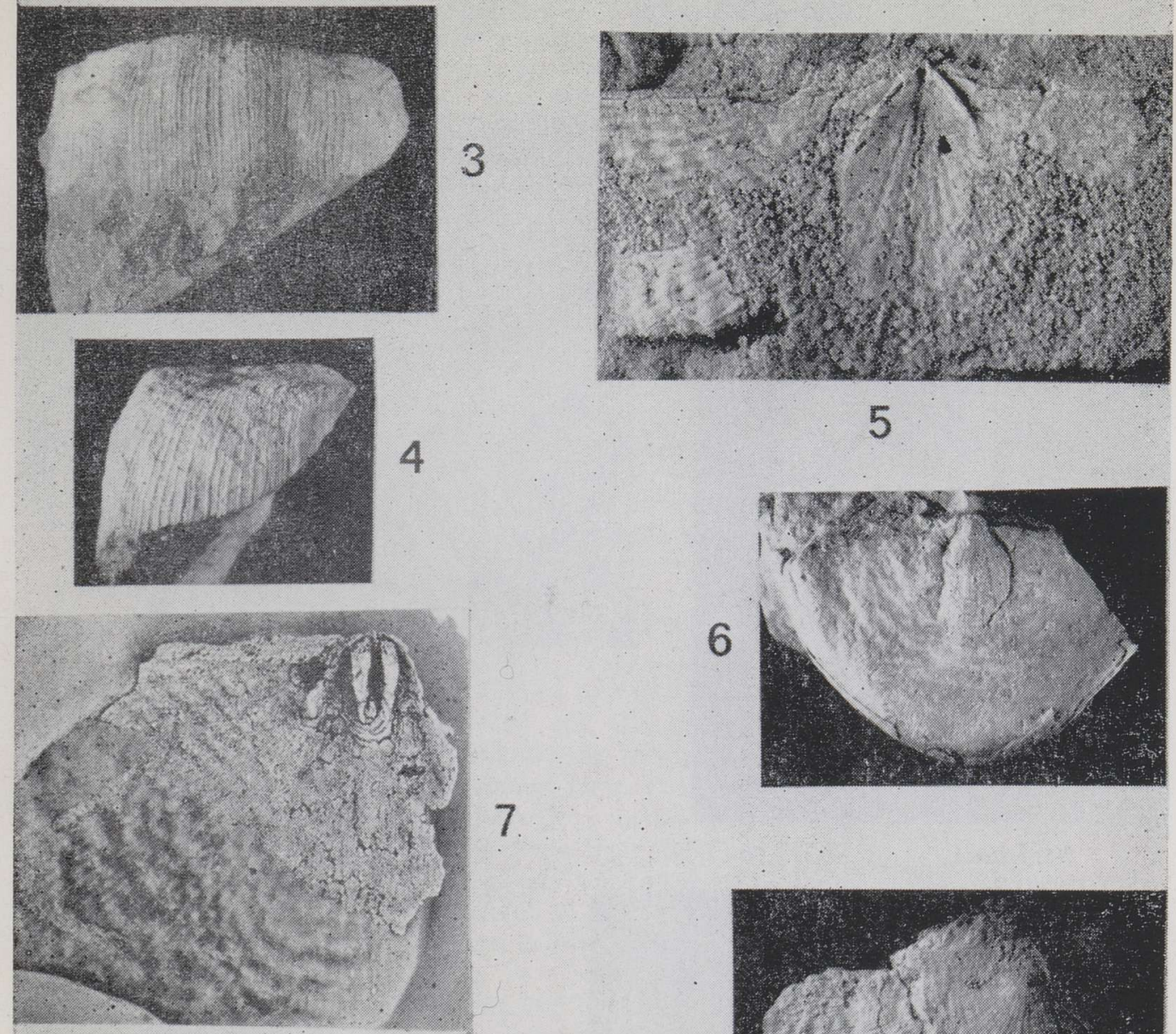

5

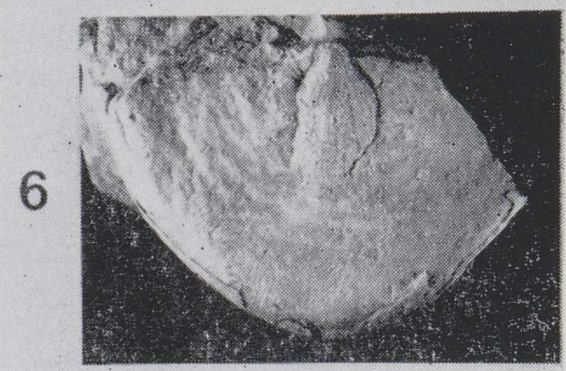

7
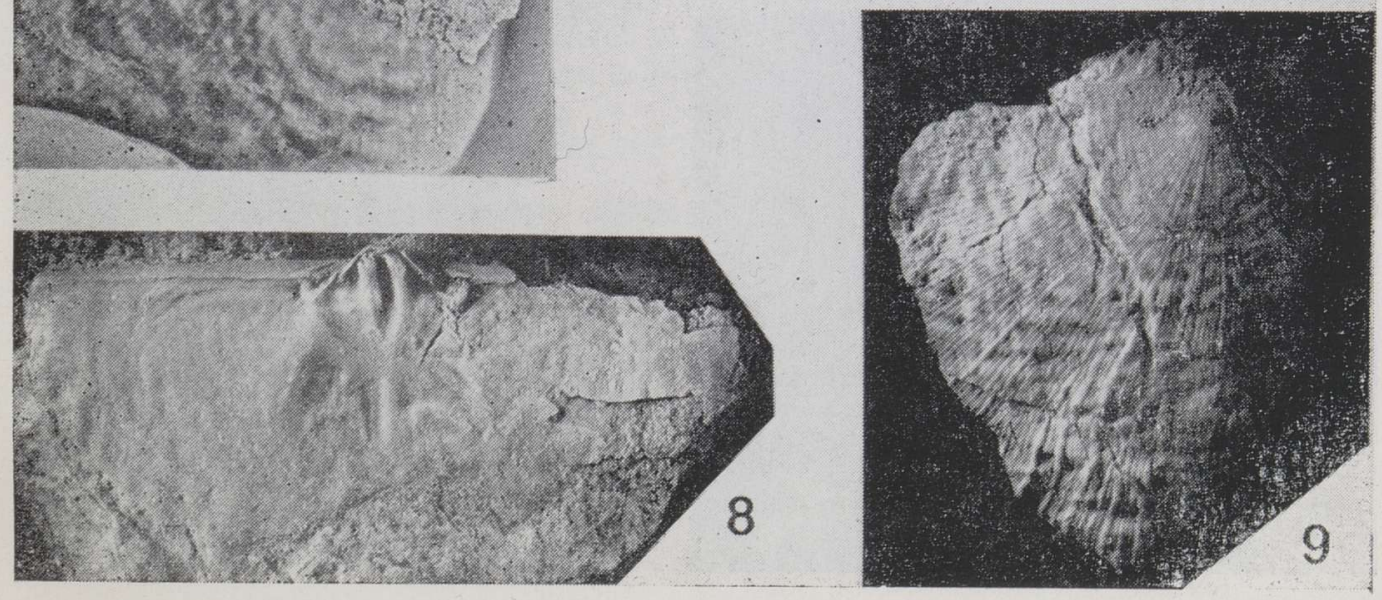
PLATE IV
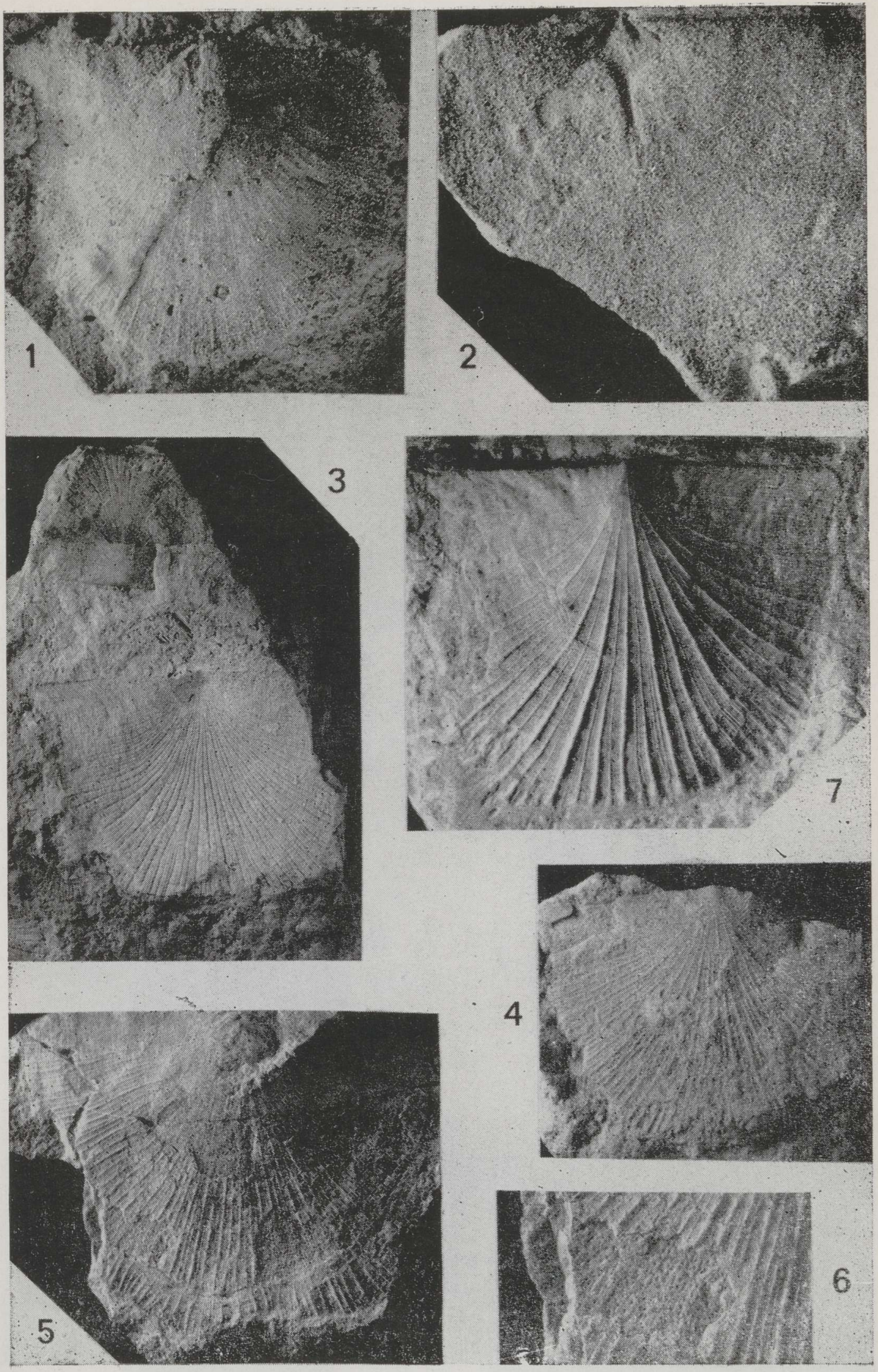

6 


\section{REFERENCES}

Bergström, J. 1968. Upper Ordovician brachiopods from Västergötland, Sweden. Geologica et Paleontologica, 2, 1-35.

Gagel, C. 1890. Die Brachiopoden der cambrischen und silurischen Geschiebe im Diluvium der Provinzen Ost- und Westpreussen. Beitr. zur Naturk. Preussens. 6 .

Holtedahl, O. 1916. Strophomenidae of the Kristiana Region. - K. Norske Vidensk. Skelsk., Skrift. 12. Kristiania.

Hurst, J. M. 1979. The stratigraphy and brachiopods of the upper part of the type Caradoc of south Salop. - Bull. Mus. Nat. Hist., London, (Geol.) 32, 4, 183-304.

Jaanusson, V. 1979. Ordovician. Treatise on Invertebrate Paleontology, Vol. A, 136-166. Jaanusson, V. and Bergström, S. 1980. Middle Ordovician faunal spatial differentiation in Baltoscandia and the Appalachians. - Alcheringa, 4, 89-110.

Martna, J. 1957. Notes on the Upper Ordovician and Lower Silurian of the Tapa district, Estonia. - Geol. Fören. Förhandl., 79, 21-34.

Salmon, E. S. 1942. Mohawkian Rafinesquinae. - J. Paleontol., 16, 564-603.

Schmidt, Fr. 1908. Beitrag zur Kenntniss ostbaltischen, vorzüglich untersilurischen, Brachiopoden der Gattungen Plectambonites Pand., Leptaena Dalm. und Strophomena Blainv. - Bull. Acad. Sci. St. Petersb., ser. VI, 11, 9, 717-726.

Алихова Т. Н. 1951. Брахиоподы нижнего силура Ленинградской области и их стратиграфическое значение. ВСЕГЕИ, Москва.

Мянниль Р. М. 1960. Стратиграфия оандуского («вазалеммаского») горизонта. ENSV TA Geol. Inst. Uurimused V. Tallinn, 89-122.

Ораспыльд А. 1956. Новые брахиоподы йыхвиского, кейлаского и вазалеммаского горизонтов. - ENSV TA Geol. Inst. Uurimused I. Tallinn, 41-67.

Рыымусокс А. 1991. О стратиграфии и фауне пограничных слоев пиргуского и поркуниского горизонтов в Северной Эстонии. - Acta et Comm. Univ. Tartuensis, 934, $23-42$.

Сокольская А. Н. 1954. Строфомениды Русской платформы. - Тр. Палеонтол. ин-та АН СССР, 51. Москва.

\section{PLATE III}

Figs. 1-7. Harjumena schmidti (Gagel), all from Nabala Stage, Saunja Formation. 1 - ventral view $(\times 1.6)$ (GMUT Br 1594). From a boulder at Pürksi, old coll. 2 ventral view (X1) (GMUT $\mathrm{Br} 1636)$. From a boulder at Käina, Hiiumaa, coll. Ignatius. $3-4$ - anterior and lateral views $(\times 1.1$ and $\times 1)$ (GMUT $\mathrm{Br}$ 1595). Kohatu, coll. A. Öpik. 5 - ventral interior (X3) (GMUT Br 1596). Odulema, coll. D. Kaljo, 1952. 6 - internal mould of the ventral interior $(X 1)$ (Naturhistoriska Riksmuseet, Stockholm, $\mathrm{Br}$ 13601). Mõnuste, coll. G. Holm. 7 - dorsal interior $(X 3)$ (Naturhistoriska Riksmuseet, Stockholm, Br 13609). Uuemōisa, coll. G. Holm. Figs. 8-9. Harjumena sp. n., all from Vormsi Stage, Kõrgessaare Formation. 8 - dorsal interior $(\times 1.4)$ (GMUT Br 1546). Kohila, coll. Fr. Schmidt. 9 - ventral view (X1) (GMUT Br 1477). Kõrgessaare, coll. Fr. Schmidt.

\section{PLATE IV}

Figs. 1-6. Pirgumena martnai sp. n., all from Pirgu Stage, Adila Formation. 1 ventral interior mould $(\times 1.5)$ (GMUT Br 1472). Röa Member, Kuru, coll. Fr. Schmidt. 2 - dorsal interior mould $(\times 1.6)$ (GMUT $\mathrm{Br} 1477$ ). Röa Member, Härküla, coll. E. Rosenstein. 3 - ventral view of the mould $(\times 1)$ (GMUT $\mathrm{Br} 1492)$ Röa Member, Aruküla-Kivisti, coll. D. Kaljo. 4 - ventral view $(\times 1.8)$ (GMUT Br 1634). Vardi, old coll. $5-6$ - ventral views of the holotype $(X 1$ and $\times 2.6)$ (GMUT $\mathrm{Br} 1471)$. Pirgu, coll. author, 1959. Fig. 7. Pirgumena sp. n., from Porkuni Stage, Siuge Member of the Arina Formation, Ventral view $(X 2)$ (GMUT Br 1467). Porkuni, coll. A. Wahl. 


\section{ULEVAADE EESTI ORDOVIITSIUMI RAFINESKVINIIDIDEST (BRACHIOPODA, STROPHOMENACEA)}

\section{Arvo ROOMUSOKS}

Eesti ordoviitsiumis esineb neli rafineskviniidide perekonda. Oandu lademe kaks Kjaerina Bancroft liiki - K. poljensis (Alichova, 1951) ja $K$. orvikui (Männil) on selle perekonna vanimad esindajad Baltikumi ordoviitsiumis. On kirjeldatud kolm uut perekonda: Rakverina, Harjumena ja Pirgumena. Viimane on Pirgu lademes esindatud uue liigiga P. martnai sp. n.

\section{ОБЗОР РАФИНЕСКВИНИД (ВRAСНIOPODA, STROPHOMENACEA) ОРДОВИКА ЭСТОНИИ}

\section{Арво РЫЫМУСОКС}

В ордовике Эстонии встречается четыре рода рафинесквинид. Два вида рода Kjaerina Bancroft - $K$. poljensis (Alichova, 1951) и $K$. orvikui (Männil) - являются старейшими представителями Kjaerina в ордовике Прибалтики. Описаны три новых рода: Rakverina, Harjumena, Pirgumena. Последний представлен в пиргуском горизонте новым видом $P$. martnai sp. п. 